DRAGANA ŠARAC, Ph.D. ${ }^{1}$

E-mail: dsarac@uns.ac.rs

MILOŠ KOPIĆ, Ph.D. ${ }^{1}$

E-mail:miloskop@uns.ac.rs

KATARINA MOSTARAC, Ph.D. Student ${ }^{2}$

(Corresponding author)

E-mail: katarina.mostarac@fpz.hr

MOMČILO KUJAČIĆ, Ph.D. ${ }^{1}$

E-mail:kujacic@uns.ac.rs

BOJAN JOVANOVIĆ, Ph.D. ${ }^{1}$

E-mail:bojanjov@uns.ac.rs

${ }^{1}$ University of Novi Sad, Faculty of Technical Sciences

Trg Dositeja Obradovića 6, 21000 Novi Sad, Serbia

2 University of Zagreb,

Faculty of Transport and Traffic Sciences

Vukelićeva 4, 10000 Zagreb, Croatia
Traffic Planning

Preliminary Communication Submitted: Oct. 7, 2015 Accepted: July 12, 2016

\title{
APPLICATION OF SET COVERING LOCATION PROBLEM FOR ORGANIZING THE PUBLIC POSTAL NETWORK
}

\begin{abstract}
Most countries of the European Union ensure certain obligations (criteria) which universal service providers must meet to ensure the realization of the universal service. These criteria vary from country to country, giving their own choice of an optimal model for the density of the postal network. Such postal network of the operator providing universal postal service must be organized so that post offices are accessible at the optimal distance from the user. This paper presents two different approaches. The first one is based on the population criteria determined in the previous study. The second one is new, a general method created to determine the minimum number of postal unit applications of Set Covering Location Problem. The authors apply both methods on real data collected from the Serbian municipalities and finally, compare the obtained results.
\end{abstract}

\section{KEY WORDS}

postal network; post office area; Set Covering Location Problem; access points;

\section{INTRODUCTION}

The universal postal service is a service of general economic interest (SGEI) and represents a set of postal services which are performed continuously on the territory of any country, within the prescribed quality, at affordable prices and under the same conditions for all users, without any discrimination [1]. The universal postal service is being developed in line with technological and economic development and the needs of the users. The provision of the universal postal service depends on the number and locations of access points. Access points are "physical facilities, including letter boxes provided for the public either on the public highway or at the premises of the postal service provider(s), where postal items may be deposited with the postal network by senders" [2]. Worldwide experience suggests different approaches in defining the components and criteria for establishing the system of access points. As can be noticed from IPC (2014) different countries have different approaches to access points (Table 1), defined by criteria as density, minimum number of permanent post offices, distribution, etc. [3].

This paper considers the postal network of public postal operator (PPO) in Serbia, as a representative of the postal operators in the region. The current trend of public postal operator and regulatory body in Serbia is to optimize the access points, universal postal service and public postal network (PPN). One possible way to achieve this goal is to minimize the number of permanent postal units of postal network. This process would reduce costs of the postal operator, as well as the total number of employees. This paper presents two different approaches to optimize the public postal network. The first one relies on previous research of Kujačić, Šarac and Jovanović (2012) and indicates the need for criteria which would determine the minimum required number of permanent postal units [4]. For the Republic of Serbia, the authors defined four relevant criteria. The second, approach for determining the required number of permanent postal units is developed in this paper. The authors use the well-known Set Covering Location Problem (SCLP) for the optimal solution of the p-centre problem. The goal of SCLP is to find the minimum number of facilities and their locations so that each node-supplier must serve the facility within the specified maximum response time or distance, 
Table 1 - PPN, number and position/location of permanent post offices

\begin{tabular}{|c|c|}
\hline & Number of post offices required \\
\hline Belgium & $\begin{array}{l}\text { Each postal service point should provide a basic assortment of public services whereas there should be } 1 \\
\text { post office per every } 10 \mathrm{~km} \text { radius with a full service offering. Furthermore, there should be at least } 1 \text { post } \\
\text { office per municipality. The Fifth Management Contract provides that bpost (universal service provider in } \\
\text { Belgium) must maintain a retail network SGEl of at least 1,300 postal service points, including post offices } \\
\text { and third-party-run postal shops. }\end{array}$ \\
\hline Croatia & $\begin{array}{l}\text { The public postal operator has an obligation to open post offices on the whole territory of the Republic of } \\
\text { Croatia under the following conditions: One post office per average area of max } 80 \mathrm{~km}^{2} \text {; One post office per } \\
\text { average number of } 6,000 \text { inhabitants }\end{array}$ \\
\hline $\begin{array}{c}\text { Czech } \\
\text { Republic }\end{array}$ & $\begin{array}{l}\text { A post office is required: in each municipality with more than } 2,500 \text { inhabitants; in each municipality with less } \\
\text { than } 2,500 \text { inhabitants and in which the registry office or building Authority and is in the municipality post } \\
\text { office; so that the distance from any location in the municipality in the Czech Republic to the post office does } \\
\text { not exceed } 10 \mathrm{~km} \text {, and so that the distance from any location, with the exception of areas that exclusively } \\
\text { serves a purpose other than housing in each village with more than } 2,500 \text { inhabitants, to the post office does } \\
\text { not exceed } 2 \mathrm{~km} \text {. }\end{array}$ \\
\hline France & $\begin{array}{l}\text { At least } 99 \% \text { of the national population and at least } 95 \% \text { of the population in each department must be less } \\
\text { than } 10 \mathrm{~km} \text { far from a post office branch. All municipalities with over } 10,000 \text { inhabitants must have at least } 1 \\
\text { post office branch per } 20,000 \text { inhabitants. } \\
\text { Additional post office network requirements do not permit more than } 10 \% \text { of a department's population to } \\
\text { be further than } 5 \mathrm{~km} \text { or more than } 20 \text { minutes by car under normal driving conditions for the area concerned } \\
\text { from the closest La Poste point of contact. }\end{array}$ \\
\hline Germany & $\begin{array}{l}12,000 \text { fixed location facilities. At least } 1 \text { permanent facility in any municipality with more than } 2,000 \\
\text { residents. Customers in any municipality with more than } 4,000 \text { residents or in adjoining built-up areas shall } \\
\text { in general be able to reach a permanent facility within no more than } 2,000 \mathrm{~m} \text {. Additionally, in every district } \\
\text { (Landkreis) } 1 \text { permanent facility shall be located per } 80 \mathrm{~km}^{2} \text {. All other locations must be served by mobile } \\
\text { postal service units. }\end{array}$ \\
\hline Hungary & $\begin{array}{l}\text { The Act on Postal Services defines the geographical availability rules of universal services as follows: Pick-up } \\
\text { points excluding street letter boxes shall not be further than } 5 \mathrm{~km} \text { from } 95 \% \text { of the population and } 10 \mathrm{~km} \\
\text { from } 99.5 \% \text { of the population. One delivery point per settlement, in case the failure of personal delivery at- } \\
\text { tempt, or poste restante services. Detailed rules to be agreed in the Universal Postal Public Service Contract. }\end{array}$ \\
\hline Italy & $\begin{array}{l}\text { Number and distribution of post offices depends on the distance of residences from the nearest post office } \\
(3 / 5 / 6 \mathrm{~km} \text { in terms of population percentage), the number of towns/ } \\
\text { villages covered by post offices (at least } 96 \%) \text {, minimum opening hours for post offices in such villages (18 } \\
\text { hours a week, } 3 \text { days a week). } \\
\text { at least } 1 \text { access point with a maximum distance of } 3 \mathrm{~km} \text { to the residences of } 75 \% \text { of the population; } \\
\text { at least } 1 \text { access point with a maximum distance of } 5 \mathrm{~km} \text { to the residences of } 92,5 \% \text { of the population, } \\
\text { at least } 1 \text { access point with a maximum distance of } 6 \mathrm{~km} \text { to the residences of } 97,5 \% \text { of the population. }\end{array}$ \\
\hline Serbia & $\begin{array}{l}\text { The universal postal service must provide access to the postal operator's network, within a reasonable } \\
\text { distance from any customer's residence. The postal operator is obliged to provide the access points' density } \\
\text { corresponding to the customer's needs, in accordance } \\
\text { with technological and economic development. }\end{array}$ \\
\hline
\end{tabular}

Source: International Postal Corporation (2014)

which we call the radius. The approach consists of three steps. The first step is to establish the network nodes which generate the demand. The second step defines the nodes candidates for public postal network. The third step is the application of p-centre problem set covering location problem. The authors of the paper use a case study of municipalities' characteristics in Serbia for numerical evaluation and testing, but the model can be applied to any postal network worldwide. After comparing the results obtained by both, the exact formulae and the SCLP model, it is observed that the second model is better for optimizing the number of access points in public postal network. The paper is organized as follows. Section 2 gives the foundations of access to the public postal operator's network. The third Section describes the new model for determining the number of permanent postal units. The following Section presents the results and discussion. The last Section 5 is devoted to concluding remarks.

\section{PREVIOUS RESEARCH ON SERBIAN PUBLIC POSTAL NETWORK}

In the next time period, the Serbian postal operator is planning a reorganization of the postal network. Since this is an extremely important activity which influences the total costs and the number of employees, it is necessary to adopt some models in order to 
determine the number of requested permanent postal units. The issue of access points and minimum number of permanent post offices are of great importance. There is no transparent methodology for the definition of particular criteria values (density of access points, minimum number of post offices, distribution/allocation of post offices on urban and rural network and other). During the research, the authors Kujačić et al. (2012) have estimated the importance of certain factors for determining the admission criteria. Based on that, they came to a conclusion that it is necessary to make certain measurements and comparisons and systematize the decision-making process. In this regard, they suggest that the tests are carried out in several steps: Step 1 - Define the scope of the universal postal service. This step significantly affects the assessment of the minimum number of post units in PPN. In the example of the Republic of Serbia, based on the scope of UPS and performance per one service [4], it is necessary to provide a minimum of one permanent post office for the inhabited area with over 1,000 residents. The number of inhabitants ni depends on $\mathrm{nm}$ numbers of minutes (norm) during the standard eight-hour day; of nwd numbers of working days during the year; of api average number of postal items per inhabited and of nmpi numbers of minutes (norm) for the transfer of one postal item (Equation 1).

$n i=\frac{n m \cdot n w d}{a p i \cdot n m p i}$

Step 2 - Determining the socio-economic and demographic characteristics of the observed country and establishing the relevant factors for the development of postal services. Step 3 - Determining the existing infrastructure of PPO and the structure of scope of universal postal service and other services provided by PPO. Step 4 - Determining the degree of correlation between environmental factors and requirements for the universal postal service. Step 5 - Determining the criteria related to the density, allocation and minimum number of access points, post offices, etc. Step 6 - Mapping and testing access points on the observed territory and assessing the minimum number of postal units. The authors Kujačić et al. (2012) defined the following criteria for urban settlements: in every settlement with more than 1,000 inhabitants (and municipalities) should be provided with at least one permanent unit of postal network; in settlements with more than 20,000 inhabitants, there has to be at least one permanent unit of postal network on every 20,000 inhabitants. According to the previously mentioned criteria, Blagojević et al., developed the following mathematical equation to determine the number of required permanent postal units: $N_{i}$ is the number of permanent postal units per municipality $i, R$ is the total number of settlements per municipality $i$ with a population between 1,000 and 20,000 inhabitants, $M$ is the total number of settlements per municipality $i$ with more than 20,000 inhabitants, $S$ is the total number of inhabitants in settlements with a population of over 20,000 inhabitants, and $j$ is the counter for settlements per municipality $i$ with more than 20,000 inhabitants [5]. This equation gives an opportunity for mathematical interpretation of the defined criteria. Obviously, Equation 2 sublimates two criteria. The first one says that a permanent postal unit has to be located in every settlement with more than 1,000 inhabitants. The binary variable xi embeds this condition into Equation 1. The second binary variable, $y_{i}$, allows criteria which says that in settlements with more than 20,000 inhabitants, at least one permanent postal unit has to exist on every 20,000 inhabitants.

$$
\begin{aligned}
& x_{i}=\left\{\begin{array}{l}
1 ; \text { exist settlement with population } \\
\text { between } 1,000 \text { and } 20,000 \\
0 ; \text { otherwise }
\end{array}\right. \\
& x_{i}=\left\{\begin{array}{l}
1 ; \text { exist settlement with population } 20,000 \\
0 ; \text { otherwise }
\end{array}\right. \\
& N_{i}=\left\lceil x_{i} R+y_{i} \sum_{j=1}^{M} \frac{S_{j}}{20,000}\right.
\end{aligned}
$$

According to the results of Kujačić et al. 2012, the minimum number of 1,052 permanent post offices must be located in the Republic of Serbia (Table 2).

\section{NEW MODEL FOR DETERMINING THE NUMBER OF PERMANENT POSTAL UNITS IN THE PUBLIC POSTAL OPERATORS' NETWORK}

The concentration of population in cities and urban population growth indicates the need to establish a proper location and number of nodes in all public

Table 2 - Evaluation of minimum number of post offices in the Republic of Serbia

\begin{tabular}{||c|c|c|c|c||}
\hline Region & $\begin{array}{c}\text { Minimum number of post } \\
\text { offices (results } \\
\text { of simulation) }\end{array}$ & $\begin{array}{c}\text { Number of post offices } \\
\text { in PPO - 2012 }\end{array}$ & $\begin{array}{c}\text { Participation of a mini- } \\
\text { mum number of post of- } \\
\text { fices in the current issue }\end{array}$ & $\begin{array}{c}\text { Participation of the mini- } \\
\text { mum number per regions }\end{array}$ \\
\hline \hline R1 & 157 & 194 & $81 \%$ & $14.92 \%$ \\
\hline R2 & 341 & 425 & $80 \%$ & $32.41 \%$ \\
\hline R3 & 554 & 863 & $64 \%$ & $52.66 \%$ \\
\hline Total & 1,052 & 1,482 & & $100.00 \%$ \\
\hline
\end{tabular}

Source: Kujacic et al. 2012 
networks (postal, telecommunication, healthcare, education, etc.). The distances that people are willing to cross on foot to reach the market place and local services are followed by the traditional local pattern of movement even though the average distances can vary from city to city. Average walk in London is 800 meters, in Midtown in the City of New York it is 534 meters while in the centre of Edmonton it is just 265 metres. In the UK, half of all trips whose purpose is shopping are to the locations that are less than 500 $\mathrm{m}$ away, of which a substantial percentage is covered by walking [6].

People are usually willing to walk to the station of public transportation that offers a higher level of service; such as the case with the railroad systems. The presence or absence of obstacles will significantly affect the experience of walking [7]. Areas projected according to public transportation stops should be within a radius of 400 to 800 metres [8]. Most people are willing to cross 500 metres to a store or the station of public transportation. There are a number of literature references on the issue of optimal walking distances [9]. There is one that talks about walking radius around stations of public transport as part of the transit-oriented development (TOD) design; there are sources in literature that talk about the health benefits of walking and the one that covers the optimal distance of permanent post offices based on the standards of some countries if compared to movement on foot. If we take $800 \mathrm{~m}$ as the maximum allowed distance of permanent housing from the permanent post offices, it can be concluded that going to and from the post office which is located at the edge of the gravitational area, the covered distance will be $1,600 \mathrm{~m}$, which falls well below the range of the recommended daily physical activity even for the oldest structure of population. In addition, there is enough room to complete other daily activities of walking up to the recommended daily optimum $(2,500 \mathrm{~m})$, if other programs and activities are not on the way to a permanent post office, which may be the case, especially in residential areas, where a small concentration of non-residential program and activities may be present, especially if it is not projected in accordance with the concentration of programs and activities in the vicinity of stations of public transport (TOD).

Within the standard that applies in the Czech Republic, where residential buildings in settlements cannot beat a distance greater than $2 \mathrm{~km}$ from the nearest post office; standard in Germany, where $100 \%$ of the population in urban areas must be located within $2 \mathrm{~km}$ from the post. This is in full accordance with the standard applicable in Switzerland, where $100 \%$ of the population has to walk to the post office for 20 minutes [3]. Slightly larger distances are in the Netherlands, where one post office is at a distance of not more than $5 \mathrm{~km}$ from the user in the city, and in Denmark, where the distance of post office from a user must not exceed $5 \mathrm{~km}$, measured in a straight line. The Netherlands and Denmark are the countries where bicycles represent the most common means of transportation. Therefore, long distances can be observed in this context.

In our research, we start from the basic gravitational area whose radius is $800 \mathrm{~m}$ of coverage. In settlements of small population density and in those that are dominated by single-family residences, the criterion of primary gravitational area does not apply. If a village or smaller town covers the surface of axle types and according to the spatial and infrastructural guidelines, stretches along the valley or along the river or the road, then a permanent postal unit should be located at the longitudinal axis of the settlement at a distance of every two diameter lengths of the gravitational area $(1,600 \mathrm{~m})$. The exception to this rule is - if there is no adequate infrastructure for the smooth movement of pedestrians, the post office should then be positioned within the primary gravitational area radius $(800 \mathrm{~m})$. This applies to settlements with high population density. This standard is in accordance with the criteria of access to postal services in the European cities (Table 1). If a village or smaller town (which by their nature are dispersed in construction and are dominated by single-family residences) covers the surface of compact shape, then permanent postal units may be allocated according to availability with respect to the distance of two diameter lengths of primary gravitational area $(1,600 \mathrm{~m})$ in relation to the entire surface. If parts of the city (which in part or majority have a high housing density) are completely or predominantly comprised of single-family housing facilities, it is necessary to have a postal unit at a distance of $1,600 \mathrm{~m}$ from the residential buildings or at a distance of two diameter lengths of the gravitational area in those parts of the city. If a city (with high population density and predominantly multi-family residential facilities) is basically of compact shape, to the entire city surface applies the criteria of a diameter gravitational area for the allocation of postal units. If the city is basically of axle type, where the smaller dimension of the surface is less than two diameters of the primary gravitational area, then the postal units are located at a distance longitudinally along the longer dimension of the settlement at a primary radius distance of a gravitational area. If the city is of combined shape type, so the settlements of 
axle types with significant roads (and in this case the dispersed settlement construction with single-family housing type) connect radially with the compact base toward the centre of gravity, then the postal units in these parts of the settlements should be arranged at a distance of two diameter lengths of the gravitational area. This applies only if along that space there is an adequate infrastructure for pedestrians. If there is no adequate infrastructure for the smooth movement of pedestrians, then the post unit must be positioned within the radius of the primary gravitational area.

Focal points represent places where inhabitants gather, such as institutions, public service buildings, facilities for culture, leisure and hospitality, sporting events, historic sites, and public gathering places for people. These places are made for public gatherings, but there is also a possibility of frequent spontaneous gathering of inhabitants. In case of places where the mass gatherings are made periodically, where a number of $f_{i}$ people gather in settlement $i$, it is necessary to connect that spatial area with a nearby primary gravitational area. In this case, we came to the conclusion that $f_{i}$ can be calculated as follows (Equation 3 ):

$f_{i}=\frac{a p i \cdot s_{i}}{n w d}$

where:

api - average number of postal items per settlement; $n w d$ - numbers of working days during the year;

$s_{i} \quad$ - number of residents in that settlement;

$f_{i}$ - minimum number of guests determines the status of the focal point in the settlement (daily average).

When we specify the radius of movement and criteria for determining the focal points in the settlements, a model of PPN can be set in three steps:

1) Establishing network nodes which generate the demand;

2) Defining nodes candidates for PPN nodes;

3) Solving the problem of determining the minimum number of post units by applying SCLP method.

\subsection{Establishing network nodes which generate demand}

We start from the basic dimensions of the gravitational area. Settlement areas are divided into squares of $\mathrm{N}$ zones whose diagonal is $800 \mathrm{~m}$ and it is also the radius of a circle circumscribed around four squareshaped zones (Figure 1). We use the Euclidean distance formula.

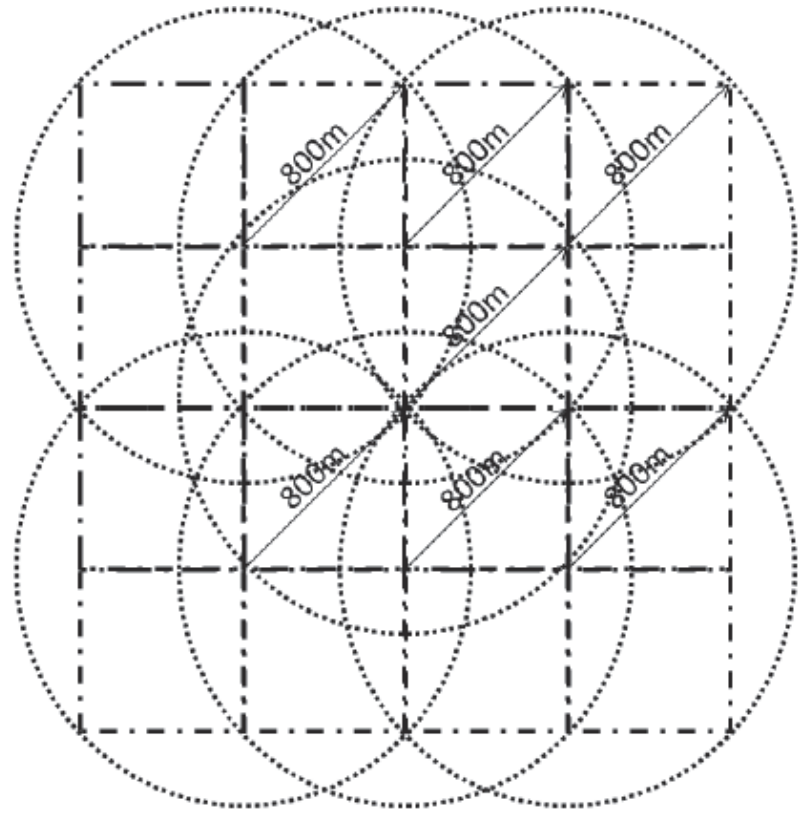

Figure 1 - Lattice structure

Thus, four square zones constitute the basic gravitational area. Possible location for the PPN nodes is in the square apices, so that the direction radius in the zone corresponds to the radius of primary gravitational area. Each apex of square zone is a node which generates demand for services [10]. The lattice structure of the settlement is organized in the following manner - vertical and horizontal lines are swiped through the focal point, which generates most gatherings; then, the grid is "stretched" left/right and up/down from the focal point, so that it covers the entire settlement area. If the focal point cannot be in the settlement, as it was previously defined, the place with the most content is taken as a starting point. This is how a network $\mathrm{G}(\mathrm{N}, \mathrm{A})$ is obtained, where $\mathrm{N}$ represents the number of nodes, A is the number of square zones for which $d=800 \mathrm{~m}$, covering the surface of the settlement.

The values 0 or 1 are assigned to obtained square zones, depending on the urban attributes of the observed zones and requirements in terms of coverage radius, i.e. the maximum acceptable distance between the located building in the PPN and the point where demand is generated ( 0 for $800 \mathrm{~m}, 1$ for $1,600 \mathrm{~m}$ ).

Zones without housing buildings, or those whose percentage of already constructed housing does not exceed $20 \%$ of the total area, are not taken into consideration to set up nodes of demand and service.

Zones are compressed into mega zones, such as type MZ4-11, MZ4-01 (1,600 m radius) and MZ2-11, MZ2-01 (radius $800 \mathrm{~m}<r<1,600 \mathrm{~m}$ ). The principles of compression are: 4 or 2 zones are connected whose value is 1 ; Compression is made in relation to the focal point, so that in the new network which is obtained after the compression $\mathrm{G}^{-}\left(\mathrm{N}^{-}, \mathrm{A}^{-}\right)$, the focal point is found 
at the intersection of 4 mega zones; Mega zone can be connected with one zone type 0 , and then they conditionally construe a mega zone. Type of this mega zone is MY4-01 and MZ2-01.

In each node in network $G^{-}\left(N^{\prime}, A^{\prime}\right)$, a node is set which generates a service request.

\subsection{Defining nodes candidates for PPN nodes}

Network nodes that are candidates for allocation of PPN nodes, in the first step, are to be placed in a network $\mathrm{G}^{-}\left(\mathrm{N}^{-}, \mathrm{A}^{-}\right)$, using the following principles: Network nodes that are candidates for allocation of PPN nodes have to be allocated at the apex of mega zones MZ4-11 and MZ2-11;Network nodes that are candidates for allocation of PPN nodes have to be allocated at the apex of zones value 0 with the zones 1 of mega zone types MZ4-01 and MZ2-01; exception to this rule are zones which have focal points in their apices; Network nodes that are candidates for allocation of PPN nodes have to be allocated at the apex of zones whose value is 0 or 1 .

\subsection{Solving the problem of determining the minimum number of post units by applying SCLP method}

The p-centre problem (first introduced by Hakimi (1964)) is to locate $p$ facility and assign it to users in order to minimize the longest distance between users and assigned facility [11]. Contrary to the p-median problem, which minimizes the sum of transportation costs, p-centre problem in the network is focused on a set of facilities that minimize the maximum distance between users and the nearest facility. There are several possible alternatives of the basic model. If the requirement is to set the requested facility in the nodes of the network, then it is called the p-centre problem on the nodes (Vertex centre problem), while the problems that allow facilities to be anywhere on a network are known as the problem of the absolute centre (Absolute centre problems). Kariv and Hakimi (1979) have shown that the problem of the p-centre in the network is an NP-hard problem [12]. Different authors have used Set Covering Location Problem (SCLP) for the optimal solution of the p-centre problem. The goal of SCLP is to find the minimum number of facilities and their locations so that each node-supplier must serve the facility within the specified maximum response time or distance, which is called radius. The solution to this problem can easily be found by solving its linear programming relaxation with the occasional application of branch-and-bound methods. When we get to the big problems, the size of the relaxed version of SCLP can be reduced by reducing the successive rows and columns. Daskin (1995) has given broader explanation of such reducing problems [13]. The first location covering problem was the set covering problem Toregas et al. (1971) [14]. Here the objective is to locate the minimum number of facilities required to "cover" all of the demand nodes. To formulate this problem the following inputs and sets are defined:

$l$ - the set of demand nodes indexed by $i$;

$J$ - the set of candidate facility locations, indexed by $j$;

$d_{i j}$ - distance between demand node $i$ and candidate site $j$;

$D_{c}$ - distance coverage;

$N_{i}=\{\mathrm{j} \mid \mathrm{dij} \leq \mathrm{Dc}\}$ - the set of all candidate locations that can cover demand point $i$ and the following decision variable

$X_{j}=\left\{\begin{array}{l}1 \text { if we locate at site } j \\ 0 \text { if not }\end{array}\right.$

With this notation, the set covering location problem (SCLP) can be formulated as follows:

Minimize $\sum_{j \in J} x_{j}$

subject to:

$$
\begin{aligned}
& \sum_{j \in N_{i}} x_{j} \geq 1 \forall i \in I \\
& x_{j} \in\{0,1\} \forall j \in J
\end{aligned}
$$

The objective function 4 minimizes the number of facilities located. Constraint set 5 ensures that each demand node is covered by at least one facility. Constraint set 6 enforces the yes or no nature of the siting decision. The objective function can be generalized by including site-specified costs as coefficients of the decision variables. In this case, the objective would be to minimize the total fixed cost of the siting configuration rather than the number of facilities sited. Both versions of the set covering problem are NP hard ones [15]. However, the linear programming relaxation of the set covering location problem as formulated above often results in an all-integer solution. Typically, only a few branches in a branch and bound algorithm are needed to obtain an optimal all-integer solution when the LP relaxation is fractional.

A variety of row and column reduction rules have been developed to reduce the size of the problem considerably [13]. For example, variable $x_{k}$ can be eliminated from the formulation if $M_{k} \subset M_{j}$, where $M_{j}=\left\{i \mid d_{i j} \leq D c\right\}$ and $M_{k}=\left\{i \mid d_{i k} \leq D c\right\}$. This column reduction is possible because a facility at $j$ would cover all of the demand nodes that a facility at $k$ would cover and possibly additional ones as well; therefore, location $j$ "dominates" location $k$. Individual constraints, say $h$, of constraint set 5 can be eliminated if there is some covering set, say $N_{i}$, such that $N_{i} \subset N_{h}$. This row reduction is possible because the constraint in 5 for demand node $h$ is redundant. That is, if the coverage constraint for demand node $i$ is satisfied, then the constraint for demand node $h$ is also satisfied. 
In this paper we shall determine nodes which generate demand. Next, network nodes that are candidates for the node of PPN (postal unit) are defined. Depending on the requirements in terms of gravitational areas and allowed distance of service level nodes from the nodes of demand, the location of nodes of PPN is determined and the total minimum number of nodes of PPN. When we define the nodes that require service and nodes that are candidates for allocation of facilities in PPN, the task was further resolved as SCLP. Set demands are related to the maximum distance of a user from the service node; cluster of nodes in network $\mathrm{G}^{-}\left(\mathrm{N}^{-}, \mathrm{A}^{-}\right)$, which generate the demand, can be presented as $B_{n}=\left\{b_{1}, b_{2}, . . b_{n}\right\}$.

$d^{*}$ is the maximum acceptable distance between facilities located inside $a_{j} \in A_{m}$ and $b_{i} \in B_{n}$, which will be served with facility $a_{j}$. If the distance between $a_{j}$ and $b_{i}$ is less than $d^{*}$, point $a_{j}$ covers point $b_{i}\left(d\left(a_{j}, b_{j}\right)<d^{*}\right)$, otherwise point $a_{j}$ does not cover $b_{i}\left(d\left(a_{j}, b_{i}\right)>d^{*}\right)$. The solution to the problem consists in finding the minimum number of points $x^{*}$ of set $A$ that can cover all the points of set $B$.

The distance between potential points and the service points can be displayed by the matrix of the shortest distance $\left[\left(d_{i j}\right)\right]$, as well as the requirements in terms of maximum acceptable distance $\left[\left(d^{*}{ }_{i j}\right)\right]$

Coverage matrix $[p(j)]$ is obtained from the following condition:

$$
p(i, j)=\left\{\begin{array}{c}
1 \text { for } d_{i j}<d_{i j}^{*} \\
0 \text { for other }
\end{array}\right.
$$

where $p(i, j)$ is the element of matrix $[p(i, j)]$ (Equation 7). Coverage matrix provides information on the coverage of user with facilities. These problems were solved by Larson and Odoni, in 1981 [16]. The aim is to reduce the number of rows in the coverage matrix to the lowest possible number, so that each column of the reduced matrix has at least one element equal to 1 . In relation to the use of methods with the requirements, we have introduced a modification which consists in introducing "step zero" [10].

Step 0 - service node must be located in the focal point -eliminate row and column passing through the focal point, as well as i columns that have the value of 1 in $i^{\star}$ row that is being removed.

Step 1-Check if there are columns whose elements are equal to 0 . If such columns exist, it is necessary to add facilities in the network in set $A$ or change minimum distance from facilities to the user.

Step 2- Investigate whether there is any column with only one element that is not 0 . Row $i^{*}$ containing this element corresponds to the place of the facility, i.e. facility must be placed in a position which corresponds to row $i^{\star}$. This point is included in the list of items that contain facilities. It is necessary to eliminate row $i$ * and all columns that have 1 in the row $i^{\star}$ of the coverage matrix.
Step 3 - Eliminate rows even if its elements are less than or equal to the corresponding elements of the second order $(p(i, j)<p(i, j)$ for $j)$.

Step 4 - Eliminate columns $\mathrm{j}$ if its elements are greater or equal to the corresponding elements of the second column $(p(i, j)>p(i, j)$ for $i)$.

Step 5 - Repeat steps 2-4 until: coverage matrix is empty or until there are no longer rows that can be eliminated.

\section{RESULTS AND DISCUSSION}

The proposed model was tested on a settlement in Serbia. The settlement has a total population of 28,239 [17]. Currently, the settlement has three permanent post offices - 3 PPN nodes, but only one post office performs all kinds of services. It is a compact shape settlement, with well-kept pedestrian and bicycle paths. All administrative, cultural and educational facilities are located in the central part of the settlement. The settlement has one focal point. Over 5,000 people gather on a daily basis in the focal point. The following is located in this area: bus station, vegetable market, police station, health centre, other types of shops and banks. Figure 2 represents the marked focal point of the settlement.

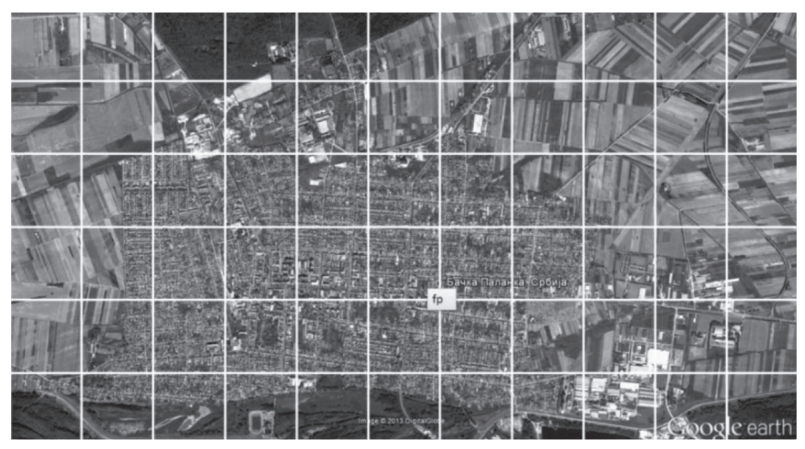

Figure 2 - Example of a settlement in Serbia

The lattice structure was set in relation to the focal point, which divided this settlement into 66 zones. Diagonal of one zone is $800 \mathrm{~m}$.

Figure 3 presents the values ( 0 or 1 ) for each zone that is considered. Zones that are marked with " $x$ " are not considered because they do not have market potential, in this particular case. These are: warehouses, industrial plants or they cover less than $20 \%$ of the zone. These zones get services from the first service point. Zone with value 0 is the zone where there are facilities such as municipalities, court of law, schools. Zone with value 1 is the zone dominated by single-family residences (The radius of this zone is $800 \mathrm{~m}$. The advantage in solving this case is that the focal point is located in one node, and that is a certain location of the service node. By compressing the zones, mega zones were obtained: 5 - MZ4-11, 1 - MZ4-01, 2 - MZ211. The allowed distance for mega zone is $1,600 \mathrm{~m}$. 


\begin{tabular}{|c|c|c|c|c|c|c|c|c|c|c|}
\hline$x$ & $x$ & $x$ & $x$ & $x$ & $x$ & $x$ & $x$ & $x$ & $x$ & $x$ \\
\hline$x$ & $x$ & $x$ & $x$ & $x$ & $x$ & $x$ & $x$ & $x$ & $x$ & $x$ \\
\hline$\times$ & 1 & 1 & 1 & 1 & 1 & 1 & 1 & $x$ & $x$ & $\times$ \\
\hline$x$ & 1 & 1 & 1 & 1 & 0 & 1 & 1 & $x$ & $\times$ & $\times$ \\
\hline$x$ & 1 & 1 & 1 & 1 & 1 & 1 & 1 & $x$ & $\times$ & $x$ \\
\hline 1 & 1 & 1 & 1 & 1 & 1 & 1 & 1 & $x$ & $x$ & $x$ \\
\hline
\end{tabular}

Figure 3 - Values of zones and mega zone

Nodes-candidates for PPN (18) as well as nodes with demand for service (18) are located in the same nodes of lattice structure (Figure 4). In node " 9 " is the focal point.

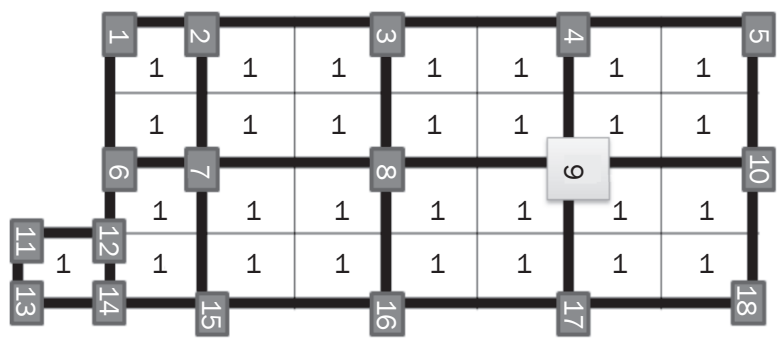

Figure 4 - Nodes-candidates for the PPN and nodes with demand for service

Table 3 shows real distances between nodes candidates for PPN and nodes with demand for service. The biggest distance is between nodes " 5 " and " 13 "-which is $5,060 \mathrm{~m}$.

All nodes demand for service except node "9" could be within allowed distance of $1,600 \mathrm{~m}$ from candidate PPN nodes. Distance node " 9 "demand for service cannot be over $800 \mathrm{~m}$.

Covering matrix is shown in Table 4. Nodes of candidates for PPN that are at a larger distance than that allowed from nodes for services demand are marked with 0 . The focal point is marked with "*”. Only node candidate for PPN marked with "9" allows distance of $800 \mathrm{~m}$ from node 9 for service demand.

It is necessary to solve the location problem as that described in Chapter 3.3. In the considered case, it was found that the settlement needs two permanent units of postal network. The location of post offices is shown in Figure 5. According to the model of Kujačić et al. (2012), in this settlement there should be a minimum of two permanent post offices (node 7 and node 9) providing all kinds of postal services.

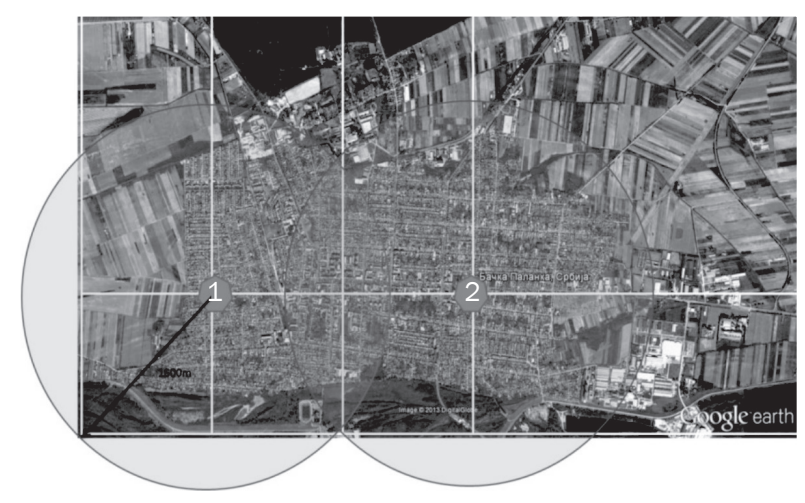

Figure 5 - Location of permanent post offices

After applying SCLP the required numbers of permanent postal units per municipalities in Serbia are obtained. These results are shown in Table 5. The authors compare results obtained by exact Equation 2 with SCLP model.

In 45 of 52 cases (settlements), SCLP model gave the number of required permanent units less than the results obtained by Equation 2. This fact is very encouraging for further implementation of this model. The obtained results indicate that the proposed model can be used in some future restructuring of the postal system, in which certainly one of the main targets will be the reduction of the number of permanent units per municipalities. The SCLP method could also be implemented to determine optimal organization of other elements of postal network (such as postal centres [18]).

\section{CONCLUSION}

The postal network capacity is a unique, strategic advantage of any post, because it allows access to the service on the internal market, and at the same time, supports the pursuit of expansion and global integration. The universal postal service network has to meet the requirements of users' access, i.e. to effectively cover the entire territory for which it is organized. That is exactly the reason why we apply two different approaches for the access to the postal network of the public operator. We apply both approaches on real data collected from the Serbian settlements. The obtained results, i.e. the number of permanent postal units per settlements in the Republic of Serbia, show that these two models are complementary and they converge to each other. This fact is very encouraging for further application of this model. The combination of described two models is suitable for application to other, similar problems related to optimization of the postal network. 


\begin{tabular}{|c|c|c|c|c|c|c|c|c|c|c|c|c|c|c|c|c|c|c|}
\hline$\stackrel{\infty}{\sim}$ & 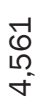 & 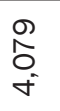 & $\begin{array}{l}\stackrel{8}{N} \\
\text { m. }\end{array}$ & 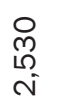 & 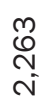 & 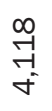 & 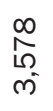 & $\begin{array}{l}\stackrel{P}{0} \\
\text { مٌ } \\
\text { N }\end{array}$ & $\begin{array}{l}8 \\
\& \\
-i\end{array}$ & $\begin{array}{l}\stackrel{-}{9} \\
\stackrel{\rightarrow}{\rightarrow}\end{array}$ & $\begin{array}{l}\text { ه } \\
\stackrel{\leftrightarrow}{\circ} \\
+\end{array}$ & $\begin{array}{l}\stackrel{8}{0} \\
\dot{+}\end{array}$ & $\begin{array}{l}\stackrel{\otimes}{\circ} \\
\stackrel{\leftrightarrow}{m} \\
m\end{array}$ & $\begin{array}{l}\stackrel{8}{0} \\
\text { ले } \\
\text { ले }\end{array}$ & $\begin{array}{l}\text { गे } \\
\text { m. } \\
\end{array}$ & $\begin{array}{l}\mathbb{N} \\
\stackrel{N}{N} \\
\sim\end{array}$ & $\underset{\rightarrow}{\stackrel{-}{\rightarrow}}$ & 0 \\
\hline 각 & $\begin{array}{l}\text { Ñ } \\
\text { Ni }\end{array}$ & $\begin{array}{l}\stackrel{\text { }}{N} \\
\text { m. }\end{array}$ & 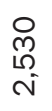 & 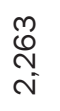 & 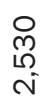 & $\begin{array}{l}0 \\
\dot{0} \\
\dot{m}\end{array}$ & $\begin{array}{l}\text { ㅇ } \\
\text { مొ } \\
\text { i }\end{array}$ & $\begin{array}{l}8 \\
\mathbb{0} \\
- \\
-1\end{array}$ & $\begin{array}{l}\vec{m} \\
\overrightarrow{-}\end{array}$ & $\begin{array}{l}8 \\
\mathbb{8} \\
- \\
-1\end{array}$ & $\begin{array}{l}\underset{f}{+} \\
\dot{m}\end{array}$ & 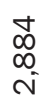 & $\begin{array}{l}\stackrel{\leftrightarrow}{m} \\
\text { m. }\end{array}$ & $\begin{array}{l}\infty \\
\stackrel{\infty}{\infty} \\
\infty \\
\stackrel{\sim}{N}\end{array}$ & 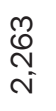 & $\begin{array}{l}\vec{m} \\
\stackrel{\rightarrow}{-}\end{array}$ & 0 & $\stackrel{\vec{m}}{\rightarrow}$ \\
\hline$\stackrel{\leftrightarrow}{\rightarrow}$ & $\begin{array}{l}\infty \\
\infty \\
\infty \\
\sim \\
\sim\end{array}$ & $\begin{array}{l}\stackrel{\cap}{N} \\
\stackrel{N}{0} \\
\stackrel{N}{N}\end{array}$ & 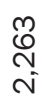 & $\begin{array}{l}\stackrel{\cap}{D} \\
\stackrel{0}{0} \\
\stackrel{N}{N}\end{array}$ & $\begin{array}{l}\stackrel{8}{ } \\
\text { m. }\end{array}$ & $\begin{array}{l}\stackrel{0}{0} \\
\text { Oे } \\
\text { i }\end{array}$ & $\begin{array}{l}8 \\
8 \\
-\end{array}$ & $\begin{array}{l}\stackrel{-1}{m} \\
\stackrel{-}{-}\end{array}$ & $\begin{array}{l}8 \\
8 \\
- \\
-1\end{array}$ & 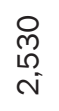 & 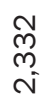 & $\begin{array}{l}\text { D } \\
\infty \\
\\
-1\end{array}$ & 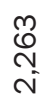 & $\begin{array}{l}\hat{8} \\
0 \\
\text { i }\end{array}$ & $\begin{array}{l}\stackrel{-1}{m} \\
\underset{-}{-}\end{array}$ & 0 & $\stackrel{\vec{m}}{\mathrm{f}}$ & 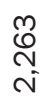 \\
\hline$\stackrel{\llcorner}{\sim}$ & 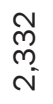 & 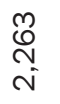 & $\begin{array}{l}\stackrel{0}{0} \\
\stackrel{N}{N} \\
\stackrel{N}{2}\end{array}$ & $\begin{array}{l}\stackrel{8}{N} \\
\text { m. }\end{array}$ & $\begin{array}{l}\stackrel{o}{0} \\
0 \\
+\end{array}$ & 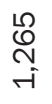 & $\stackrel{\vec{m}}{\rightarrow}$ & $\begin{array}{l}8 \\
0 \\
i \\
-\end{array}$ & 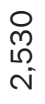 & 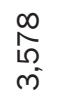 & 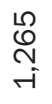 & $\stackrel{\infty}{\infty}$ & $\begin{array}{l}\stackrel{-1}{\vec{m}} \\
\stackrel{-}{-}\end{array}$ & $\begin{array}{l}0 \\
i \\
i n\end{array}$ & 0 & $\begin{array}{l}\stackrel{-1}{9} \\
\stackrel{\leftrightarrow}{-}\end{array}$ & $\begin{array}{l}\mathbb{N} \\
\stackrel{N}{N} \\
\sim\end{array}$ & $\begin{array}{l}\text { गे } \\
\text { m. }\end{array}$ \\
\hline$\underset{\neg}{ }$ & 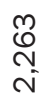 & $\begin{array}{c}\stackrel{N}{m} \\
\stackrel{N}{N}\end{array}$ & $\begin{array}{l}\infty \\
N \\
\infty \\
\stackrel{N}{N}\end{array}$ & $\begin{array}{l}\mathcal{N} \\
\stackrel{M}{m} \\
\dot{m}\end{array}$ & 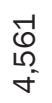 & $\underset{\stackrel{m}{-}}{\vec{r}}$ & 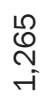 & $\begin{array}{l}\text { o } \\
\text { o } \\
\text { i }\end{array}$ & \begin{tabular}{l}
0 \\
\multirow{0}{*}{} \\
$\dot{m}$
\end{tabular} & $\begin{array}{l}\infty \\
\underset{\sim}{\rightarrow}\end{array}$ & $\underset{\infty}{\stackrel{\infty}{ }}$ & $\begin{array}{l}\mathscr{0} \\
\stackrel{1}{ }\end{array}$ & 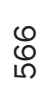 & 0 & $\begin{array}{l}0 \\
\stackrel{0}{0} \\
\llcorner\end{array}$ & $\begin{array}{l}\hat{a} \\
0 \\
- \\
-\end{array}$ & $\begin{array}{l}\infty \\
N \\
\infty \\
\sim \\
\sim\end{array}$ & 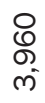 \\
\hline$\stackrel{m}{\rightarrow}$ & 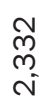 & 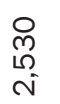 & $\begin{array}{l}\stackrel{\circ}{N} \\
\text { m. }\end{array}$ & $\begin{array}{l}\text { o } \\
\tilde{0} \\
\dot{\sigma}\end{array}$ & $\begin{array}{l}\& \\
\varnothing \\
\text { in }\end{array}$ & 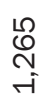 & $\begin{array}{l}8 \\
8 \\
-1\end{array}$ & 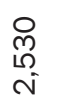 & 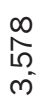 & 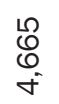 & $\begin{array}{l}\bigotimes \\
\vdots \\
i\end{array}$ & ষ্ঠ & 0 & $\begin{array}{l}\mathscr{0} \\
\stackrel{0}{0}\end{array}$ & $\underset{\stackrel{\vec{m}}{\rightarrow}}{\stackrel{-1}{r}}$ & 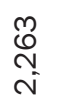 & $\begin{array}{l}\text { मे } \\
\text { mे }\end{array}$ & 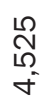 \\
\hline ส & $\begin{array}{l}\hat{8} \\
\stackrel{8}{-} \\
-1\end{array}$ & 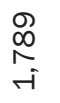 & $\begin{array}{l}\stackrel{8}{o} \\
\stackrel{N}{*}\end{array}$ & 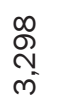 & $\begin{array}{l}\infty_{0}^{\infty} \\
\text { m } \\
\sim\end{array}$ & $\begin{array}{l}0 \\
\stackrel{0}{0} \\
\text { L }\end{array}$ & $\underset{\infty}{\infty}$ & 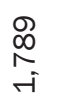 & 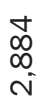 & $\begin{array}{l}8 \\
8 \\
\dot{*}\end{array}$ & $\begin{array}{l}\bigotimes \\
\text { in }\end{array}$ & 0 & ৪ & $\begin{array}{l}0 \\
\stackrel{0}{ }\end{array}$ & $\stackrel{8}{\varnothing}$ & $\begin{array}{l}\infty \\
\infty \\
\stackrel{-}{r}\end{array}$ & 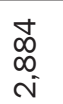 & $\begin{array}{l}\stackrel{8}{\circ} \\
\stackrel{-}{*}\end{array}$ \\
\hline 각 & $\begin{array}{l}\mathscr{D} \\
\stackrel{\sim}{\sim} \\
\stackrel{-}{n}\end{array}$ & $\begin{array}{l}\text { o } \\
\text { O } \\
\text { i }\end{array}$ & $\begin{array}{l}\infty \\
N \\
\infty \\
\stackrel{N}{N}\end{array}$ & 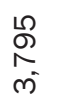 & $\underset{\substack{\infty \\
\infty \\
\infty}}{\stackrel{\infty}{*}}$ & ষ্ঠ & $\begin{array}{l}\stackrel{L}{0} \\
\underset{\sim}{+}\end{array}$ & $\begin{array}{c}\stackrel{N}{N} \\
\stackrel{N}{N}\end{array}$ & $\begin{array}{l}\underset{f}{+} \\
\dot{\varpi}\end{array}$ & $\begin{array}{l}\overrightarrow{0} \\
0 \\
\stackrel{1}{\sigma}\end{array}$ & 0 & $\begin{array}{l}\mathscr{0} \\
\notin \\
\llcorner\end{array}$ & 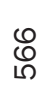 & ஜ & $\begin{array}{l}\stackrel{\leftrightarrow}{0} \\
\stackrel{\sim}{\sim}\end{array}$ & $\begin{array}{c}\text { N్} \\
\text { N } \\
\stackrel{N}{N}\end{array}$ & 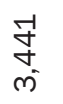 & $\begin{array}{l}\overrightarrow{0} \\
\stackrel{0}{\rho} \\
\forall\end{array}$ \\
\hline 악 & 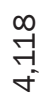 & 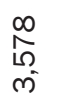 & $\begin{array}{l}\stackrel{\cap}{n} \\
\stackrel{\leftrightarrow}{\sim} \\
\stackrel{N}{n}\end{array}$ & $\begin{array}{l}8 \\
8 \\
-i\end{array}$ & $\begin{array}{l}\vec{m} \\
\stackrel{-}{-}\end{array}$ & $\begin{array}{l}\text { \&े } \\
\text { ले }\end{array}$ & $\begin{array}{l}\text { गे } \\
\text { m. }\end{array}$ & 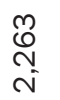 & $\begin{array}{l}\vec{m} \\
\overrightarrow{-}\end{array}$ & 0 & 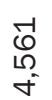 & $\begin{array}{l}8 \\
8 \\
\dot{\forall}\end{array}$ & 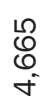 & $\begin{array}{l}\stackrel{\infty}{\rightarrow} \\
\underset{\sim}{-}\end{array}$ & 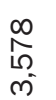 & 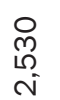 & $\begin{array}{l}\underset{+}{0} \\
\underset{+}{+}\end{array}$ & $\stackrel{\vec{m}}{\stackrel{-}{-}}$ \\
\hline の & $\begin{array}{l}0 \\
\text { Oे } \\
\dot{m}\end{array}$ & 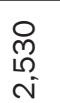 & $\begin{array}{l}8 \\
8 \\
i \\
-i\end{array}$ & $\stackrel{\stackrel{-}{m}}{\stackrel{-}{-}}$ & \begin{tabular}{l}
8 \\
8 \\
\hdashline \\
-1
\end{tabular} & \begin{tabular}{c}
$\infty$ \\
$\stackrel{\infty}{\infty}$ \\
\multirow{\sim}{*}{}
\end{tabular} & 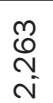 & $\stackrel{\vec{m}}{\stackrel{-}{-}}$ & 0 & $\stackrel{\vec{m}}{\stackrel{-}{-}}$ & $\begin{array}{l}\stackrel{f}{\&} \\
\stackrel{m}{m}\end{array}$ & $\begin{array}{l}+ \\
\infty \\
\infty \\
\sim \\
\sim\end{array}$ & $\begin{array}{l}\infty \\
\stackrel{\infty}{L} \\
\stackrel{n}{n}\end{array}$ & $\begin{array}{l}0 \\
\text { Oे } \\
\dot{m}\end{array}$ & $\begin{array}{l}\stackrel{\overbrace{}}{N} \\
\stackrel{D}{N} \\
\text { N }\end{array}$ & $\begin{array}{l}8 \\
8 \\
i \\
-1\end{array}$ & $\stackrel{\vec{m}}{\stackrel{-}{r}}$ & $\begin{array}{l}8 \\
\stackrel{-}{0} \\
-i\end{array}$ \\
\hline$\infty$ & $\begin{array}{l}\text { o } \\
\text { O } \\
\text { i }\end{array}$ & $\begin{array}{l}\stackrel{8}{0} \\
\stackrel{+}{-}\end{array}$ & $\stackrel{\vec{m}}{\stackrel{-}{-}}$ & $\begin{array}{l}8 \\
0 \\
0 \\
-i\end{array}$ & 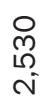 & 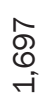 & $\begin{array}{l}\vec{y} \\
\vec{\pi} \\
\overrightarrow{-1}\end{array}$ & 0 & & 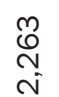 & $\begin{array}{c}\underset{m}{m} \\
\stackrel{N}{N}\end{array}$ & $\begin{array}{l}\stackrel{\infty}{\infty} \\
\stackrel{-}{+}\end{array}$ & 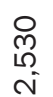 & $\begin{array}{l}\text { o } \\
\text { Oे }\end{array}$ & $\begin{array}{l}8 \\
\mathbb{8} \\
-\end{array}$ & $\underset{\vec{\sim}}{\vec{\sim}}$ & $\begin{array}{l}8 \\
8 \\
i\end{array}$ & 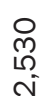 \\
\hline N & \begin{tabular}{l}
$\stackrel{\llcorner}{0}$ \\
\multirow{\sim}{*}{}
\end{tabular} & $\begin{array}{l}\stackrel{-}{m} \\
\stackrel{-}{-}\end{array}$ & $\begin{array}{l}8 \\
8 \\
-i\end{array}$ & $\begin{array}{l}\stackrel{O}{n} \\
\text { Ln } \\
\text { N }\end{array}$ & $\begin{array}{l}\infty \\
\stackrel{\infty}{L} \\
m_{n}^{2}\end{array}$ & $\begin{array}{l}0 \\
\notin \\
\llcorner\end{array}$ & 0 & $\begin{array}{l}\stackrel{-}{m} \\
\stackrel{-}{-}\end{array}$ & 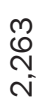 & 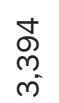 & 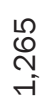 & $\underset{\infty}{\infty}$ & $\begin{array}{l}8 \\
8 \\
-1\end{array}$ & $\begin{array}{l}\stackrel{\leftrightarrow}{0} \\
\stackrel{\leftrightarrow}{\sim}\end{array}$ & $\begin{array}{l}\vec{m} \\
\stackrel{-}{-}\end{array}$ & $\begin{array}{l}8 \\
8 \\
i \\
-1\end{array}$ & 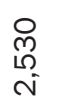 & $\begin{array}{l}\infty \\
\stackrel{\infty}{L} \\
\stackrel{n}{m}\end{array}$ \\
\hline 0 & $\underset{\vec{r}}{\stackrel{\vec{m}}{\rightarrow}}$ & $\begin{array}{l}\stackrel{L}{0} \\
\stackrel{\leftrightarrow}{\sim} \\
\underset{\sim}{-1}\end{array}$ & 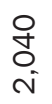 & $\begin{array}{l}0 \\
\text { Oे } \\
\dot{m}\end{array}$ & $\underset{\underset{f}{\rightarrow}}{\stackrel{\infty}{\rightarrow}}$ & 0 & $\begin{array}{l}0 \\
\& \\
\wp\end{array}$ & $\begin{array}{l}\hat{8} \\
\hat{-}\end{array}$ & 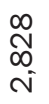 & $\begin{array}{l}\stackrel{.}{ } \\
\stackrel{\circ}{m} \\
\text { m. }\end{array}$ & $\stackrel{\infty}{\infty}$ & $\begin{array}{l}0 \\
\bigotimes \\
\llcorner\end{array}$ & 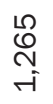 & $\begin{array}{l}\vec{m} \\
\stackrel{-}{-}\end{array}$ & $\begin{array}{l}\stackrel{L}{0} \\
\stackrel{\sim}{\sim} \\
\sim\end{array}$ & $\begin{array}{l}\text { o } \\
\text { O } \\
\text { i }\end{array}$ & $\begin{array}{l}0 \\
\text { Oे } \\
\dot{m}\end{array}$ & 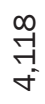 \\
\hline مـ & 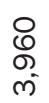 & $\begin{array}{l}\text { गे } \\
\text { m. }\end{array}$ & 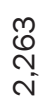 & $\begin{array}{l}\vec{m} \\
\stackrel{-}{-}\end{array}$ & 0 & \begin{tabular}{l}
$\infty$ \\
$\underset{\sim}{\rightarrow}$ \\
\multirow{\sigma}{*}{}
\end{tabular} & $\begin{array}{l}\infty \\
\stackrel{\infty}{1} \\
\stackrel{n}{m}\end{array}$ & 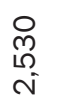 & $\begin{array}{l}8 \\
8 \\
-i\end{array}$ & $\begin{array}{l}\vec{m} \\
\stackrel{\rightarrow}{-}\end{array}$ & $\underset{\substack{M \\
\infty \\
\infty \\
\sim \\
\sim}}{ }$ & \begin{tabular}{l}
$\infty$ \\
$\stackrel{m}{m}$ \\
\multirow{r}{*}{}
\end{tabular} & $\begin{array}{l}\stackrel{8}{\circ} \\
\text { is }\end{array}$ & $\begin{array}{l}\overrightarrow{0} \\
\stackrel{0}{0} \\
\stackrel{\sigma}{*}\end{array}$ & $\begin{array}{l}\stackrel{9}{0} \\
0 \\
\dot{f}\end{array}$ & $\begin{array}{l}\stackrel{8}{ } \\
\text { m}\end{array}$ & 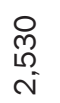 & 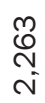 \\
\hline$\nabla$ & $\begin{array}{l}\infty \\
\sim \\
\infty \\
\sim \\
\sim\end{array}$ & 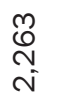 & $\stackrel{\vec{m}}{\rightarrow}$ & 0 & $\begin{array}{l}\vec{m} \\
\stackrel{-}{-}\end{array}$ & $\begin{array}{l}0 \\
\text { Oे } \\
\text { m. }\end{array}$ & $\begin{array}{l}\stackrel{N}{n} \\
\stackrel{\leftrightarrow}{N} \\
\text { Ni }\end{array}$ & $\begin{array}{l}\stackrel{8}{0} \\
\stackrel{-}{-1}\end{array}$ & $\begin{array}{l}\vec{m} \\
\overrightarrow{-} \\
\vec{r}\end{array}$ & $\begin{array}{l}\stackrel{8}{0} \\
\stackrel{-}{-}\end{array}$ & 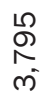 & 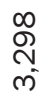 & 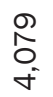 & $\begin{array}{l}\text { N̦ } \\
\text { m. }\end{array}$ & $\begin{array}{l}\stackrel{\text { N }}{m} \\
\text { m. }\end{array}$ & 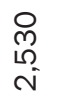 & 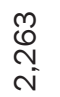 & 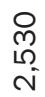 \\
\hline$m$ & ô & $\begin{array}{l}\stackrel{-}{m} \\
\underset{-}{-}\end{array}$ & 0 & $\stackrel{\stackrel{-1}{9}}{\underset{-}{-}}$ & 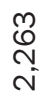 & $\begin{array}{l}\text { o } \\
\text { O } \\
\text { i }\end{array}$ & $\begin{array}{l}8 \\
8 \\
-i\end{array}$ & $\begin{array}{l}\vec{m} \\
\vec{\rightarrow}\end{array}$ & $\begin{array}{l}8 \\
\varnothing \\
- \\
-\end{array}$ & 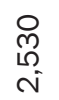 & $\begin{array}{l}\underset{N}{N} \\
\infty \\
\stackrel{N}{N}\end{array}$ & $\begin{array}{l}\text { ৪ } \\
\stackrel{+}{\sim}\end{array}$ & 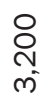 & $\begin{array}{l}\infty \\
\sim \\
\infty \\
\stackrel{N}{N}\end{array}$ & 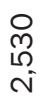 & 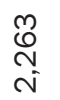 & 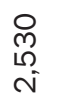 & $\begin{array}{l}\stackrel{\text { }}{\text { N }} \\
\text { m) }\end{array}$ \\
\hline$N$ & $\begin{array}{l}\mathscr{Q} \\
\stackrel{\leftrightarrow}{i}\end{array}$ & 0 & $\begin{array}{l}\stackrel{-1}{m} \\
\overrightarrow{-}\end{array}$ & 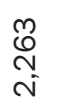 & $\begin{array}{l}\text { Dे } \\
\text { m. }\end{array}$ & $\begin{array}{l}\stackrel{0}{0} \\
\underset{\sim}{\sim}\end{array}$ & $\begin{array}{l}\overrightarrow{-} \\
\stackrel{-}{-}\end{array}$ & $\begin{array}{l}\stackrel{8}{0} \\
\stackrel{-}{-}\end{array}$ & 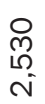 & $\begin{array}{l}\infty \\
\stackrel{1}{\omega} \\
m\end{array}$ & $\begin{array}{l}\text { o } \\
\text { Oे } \\
\text { i }\end{array}$ & $\begin{array}{l}\mathscr{D} \\
\stackrel{2}{\sim} \\
\stackrel{-}{-1}\end{array}$ & 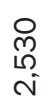 & 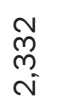 & 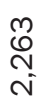 & $\begin{array}{l}\stackrel{D}{D} \\
\text { దn } \\
\text { Ni }\end{array}$ & $\begin{array}{l}\underset{N}{\stackrel{2}{n}} \\
\text { m. }\end{array}$ & 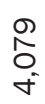 \\
\hline - & 0 & $\begin{array}{l}0 \\
\notin \\
\emptyset\end{array}$ & $\begin{array}{l}\hat{8} \\
0 \\
\text { - }\end{array}$ & 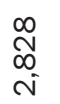 & $\begin{array}{l}\text { \&े } \\
\text { ले }\end{array}$ & $\begin{array}{l}\vec{m} \\
\stackrel{\rightarrow}{r}\end{array}$ & $\begin{array}{l}\stackrel{0}{0} \\
\stackrel{\leftrightarrow}{\sim}\end{array}$ & $\begin{array}{l}\text { o } \\
\text { Oे } \\
\text { i }\end{array}$ & $\begin{array}{l}0 \\
0 \\
0 \\
\dot{m}\end{array}$ & 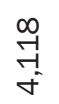 & $\begin{array}{l}\stackrel{D}{\infty} \\
\stackrel{D}{+} \\
-i\end{array}$ & $\begin{array}{l}\hat{8} \\
0 \\
\text { - }\end{array}$ & 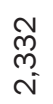 & 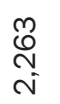 & $\begin{array}{c}\text { N్} \\
\text { N } \\
\text { Ni }\end{array}$ & 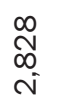 & $\begin{array}{l}\text { స్ } \\
\stackrel{m}{m}\end{array}$ & 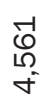 \\
\hline & 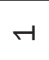 & $N$ & $m$ & $\sigma$ & ما & 0 & N & $\infty$ & $\sigma$ & 우 & $\exists$ & 각 & $\stackrel{m}{\rightarrow}$ & $\underset{\sim}{J}$ & $\stackrel{\text { I }}{\rightarrow}$ & $\stackrel{\varphi}{\sim}$ & ને & $\stackrel{\infty}{\rightarrow}$ \\
\hline & \multicolumn{18}{|c|}{ 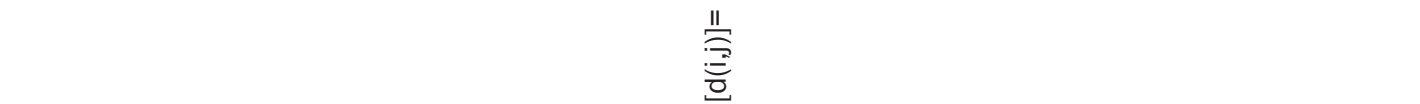 } \\
\hline
\end{tabular}


Table 4 - Covering matrix

\begin{tabular}{|c|c|c|c|c|c|c|c|c|c|c|c|c|c|c|c|c|c|c|c|}
\hline & & 1 & 2 & 3 & 4 & 5 & 6 & 7 & 8 & 9 & 10 & 11 & 12 & 13 & 14 & 15 & 16 & 17 & 18 \\
\hline \multirow{18}{*}[p(i,j)]{$=$} & 1 & 1 & 1 & 0 & 0 & 0 & 1 & 1 & 0 & 0 & 0 & 0 & 0 & 0 & 0 & 0 & 0 & 0 & 0 \\
\hline & 2 & 1 & 1 & 1 & 0 & 0 & 1 & 1 & 1 & 0 & 0 & 0 & 0 & 0 & 0 & 0 & 0 & 0 & 0 \\
\hline & 3 & 0 & 1 & 1 & 1 & 0 & 0 & 1 & 1 & 0 & 0 & 0 & 0 & 0 & 0 & 0 & 0 & 0 & 0 \\
\hline & 4 & 0 & 0 & 1 & 1 & 1 & 0 & 0 & 1 & 0 & 1 & 0 & 0 & 0 & 0 & 0 & 0 & 0 & 0 \\
\hline & 5 & 0 & 0 & 0 & 1 & 1 & 0 & 0 & 0 & 0 & 1 & 0 & 0 & 0 & 0 & 0 & 0 & 0 & 0 \\
\hline & 6 & 1 & 1 & 0 & 0 & 0 & 1 & 1 & 0 & 0 & 0 & 1 & 1 & 1 & 1 & 1 & 0 & 0 & 0 \\
\hline & 7 & 1 & 1 & 1 & 0 & 0 & 1 & 1 & 0 & 0 & 1 & 1 & 1 & 1 & 1 & 1 & 1 & 0 & 0 \\
\hline & 8 & 0 & 1 & 1 & 1 & 0 & 0 & 1 & 0 & 0 & 0 & 0 & 0 & 0 & 0 & 1 & 1 & 1 & 0 \\
\hline & 9 & 0 & 0 & 1 & 1 & 1 & 0 & 0 & $1 *$ & 1 & 0 & 0 & 0 & 0 & 0 & 0 & 1 & 1 & 1 \\
\hline & 10 & 0 & 0 & 0 & 1 & 1 & 0 & 0 & 0 & 0 & 1 & 0 & 0 & 0 & 0 & 0 & 0 & 1 & 1 \\
\hline & 11 & 0 & 0 & 0 & 0 & 0 & 1 & 1 & 0 & 0 & 0 & 1 & 1 & 1 & 1 & 1 & 0 & 0 & 0 \\
\hline & 12 & 0 & 0 & 0 & 0 & 0 & 1 & 1 & 0 & 0 & 0 & 1 & 1 & 1 & 1 & 1 & 0 & 0 & 0 \\
\hline & 13 & 0 & 0 & 0 & 0 & 0 & 1 & 1 & 0 & 0 & 0 & 1 & 1 & 1 & 1 & 1 & 0 & 0 & 0 \\
\hline & 14 & 0 & 0 & 0 & 0 & 0 & 1 & 1 & 0 & 0 & 0 & 1 & 1 & 1 & 1 & 1 & 0 & 0 & 0 \\
\hline & 15 & 0 & 0 & 0 & 0 & 0 & 1 & 1 & 1 & 0 & 0 & 1 & 1 & 1 & 1 & 1 & 1 & 0 & 0 \\
\hline & 16 & 0 & 0 & 0 & 0 & 0 & 0 & 1 & 1 & 0 & 0 & 0 & 0 & 0 & 0 & 1 & 1 & 1 & 0 \\
\hline & 17 & 0 & 0 & 0 & 0 & 0 & 0 & 0 & 1 & 0 & 1 & 0 & 0 & 0 & 0 & 0 & 1 & 1 & 1 \\
\hline & 18 & 0 & 0 & 0 & 0 & 0 & 0 & 0 & 0 & 0 & 1 & 0 & 0 & 0 & 0 & 0 & 0 & 1 & 1 \\
\hline
\end{tabular}

Table 7 - Comparison of obtained results.

\begin{tabular}{||c|c|c|c||}
\hline $\begin{array}{c}\text { Number } \\
\text { of inhabitants }\end{array}$ & $\begin{array}{c}\text { Number of } \\
\text { settle- } \\
\text { ments }\end{array}$ & $\begin{array}{c}\text { Results } \\
\text { obtained } \\
\text { by Eq. (2) }\end{array}$ & $\begin{array}{c}\text { Number of } \\
\text { perma- } \\
\text { nent } \\
\text { postal } \\
\text { units by } \\
\text { SCLP }\end{array}$ \\
\hline \hline $20,000-30,000$ & 14 & 26 & 26 \\
\hline $30,000-40,000$ & 9 & 18 & 17 \\
\hline $40,000-50,000$ & 4 & 9 & 9 \\
\hline $50,000-60,000$ & 8 & 24 & 23 \\
\hline $60,000-70,000$ & 3 & 12 & 11 \\
\hline $70,000-80,000$ & 4 & 16 & 16 \\
\hline $90,000-100,000$ & 1 & 5 & 5 \\
\hline $100,000-110,000$ & 2 & 12 & 13 \\
\hline $130,000-140,000$ & 2 & 16 & 15 \\
\hline $140,000-150,000$ & 2 & 16 & 16 \\
\hline $150,000-160,000$ & 1 & 8 & 8 \\
\hline $210,000-220,000$ & 1 & 11 & 11 \\
\hline $220,000-230,000$ & 1 & 12 & 12 \\
\hline TOTAL & 52 & 185 & 182 \\
\hline
\end{tabular}

The scientific contributions developed and presented in this paper are the following:

- modification of SCLP method to meet the needs in the postal sector, by determining the minimum number and location of units of the postal network, for the provision of the universal postal service,

- defining the criteria for determining the minimum radius that is the distance between nodes candidates for PPN nodes and nodes that generate demand $(800 \mathrm{~m}$ or $1,600 \mathrm{~m})$,

- the number of visitors that determine the status focal point in the village $\left(f_{j}\right)$ is mathematically specified.

\section{Dr DRAGANA ŠARAC ${ }^{1}$}

E-mail: dsarac@uns.ac.rs Dr MILOŠ KOPIĆ ${ }^{1}$

E-mail:miloskop@uns.ac.rs

KATARINA MOSTARAC, doktorand ${ }^{2}$

E-mail: katarina.mostarac@fpz.hr

Dr MOMČILO KUJAČIĆ ${ }^{1}$

E-mail:kujacic@uns.ac.rs

Dr BOJAN JOVANOVIĆ1

E-mail:bojanjov@uns.ac.rs

${ }^{1}$ Univerzitet u Novom Sadu, Fakultet tehničkih nauka

Trg Dositeja Obradovića 6, 21000 Novi Sad, Srbija

2 Sveučilište u Zagrebu, Fakultet prometnih znanosti

Vukelićeva 4, 10000 Zagreb, Hrvatska

\section{PRIMENA LOKACIJSKOG PROBLEMA POKRIVANJA SKUPA U ORGANIZACIJI JAVNE POŠTANSKE MREŽE}

\section{ABSTRAKT}

Većina zemalja Evropske Unije nastoji osigurati određene obaveze (kriterijume) koje provajderi univerzalne usluge moraju ispuniti kako bi se obezbedilo pružanje univerzalne 
usluge. Ovi kriterijumi razlikuju se od zemlje do zemlje i daju doprinos izboru optimalnog modela za gustinu poštanske mreže. Takva poštanska mreža operatora koji pruža univerzalnu poštansku uslugu mora biti organizovana na taj način da poštanske jedinice budu dostupne na optimalnoj udaljenosti od korisnika. U ovom radu ćemo predstaviti dva različita pristupa. Prvi se temelji na kriterijumu broja stanovnika utvrđenih u prethodnom istraživanju. Drugi je novi, opšti, metod stvoren kako bi se utvrdilo minimalni broj poštanskih jedinica primenom lokacijskog problema pokrivanja skupa. Autori će primeniti oba pristupa na realnim podacima prikupljenim iz opština u Srbiji i konačno, uporeditiće rezultate dobijene putem oba pristupa.

\section{KLUUČNE REČI}

poštanska mreža; područje pošte; lokacijski problem pokrivanja skupa; pristupne točke;

\section{REFERENCES}

[1] European Parliament and the Council. Accompanying document to the Report from the Commission to the European Parliament and the Council on the application of the Postal Directive (Directive 97/67/EC as amended by Directive 2002/39/EC) \{COM(2008) 884 final\};2008.p. 19-20.

[2] ERGP. ERGP REPORT on "access" to the postal network and elements ofpostal infrastructure; 2012.

[3] International Postal Corporation. Postal Regulatory Database, Country Directory; 2014.

[4] Kujačić M, Šarac D, Jovanović B. Access to the postal network of the public operator. Proceedings of the SEETSI \& Regional Conference the Role or Strategic Partnership and Re Engineering or the Public Postal Network in the Sustainable Provision or Universal Service; 2012 Oct 16; Budva, Montenegro; 2012. p. 15-27.

[5] Blagojević M, Šemlić M, Macura D, Šarac D. Determining the number of postal units in the network - Fuzzy approach, Serbia case study. Expert Systems with Applications. 2013;10:4090-4095.
[6] Zacharias J. Pedestrian Behavior and Perception in Urban Walking Environments. Journal of Planning Literature. 2001;16(1):3-18.

[7] Cervero R, Ferrell C, Murphy S. Transit-Oriented Development and Joint Development in the United States: A Literature Review. Research Results Digest. Oct 2002;(52):1-144.

[8] Regional Plan Association. Building Transit - Friendly Communities A Design and Development Strategy for the Tri-State Metropolitan Region. New York, New Jersey, Connecticut; 1997.

[9] Millward H, Spinney J, Scott D. Active-transport walking behavior: destinations, durations, distances. Journal of Transport Geography. 2013;28:101-110.

[10] ŠaracD, Kujačić M, Dumnić S. Determination numbers of nodes in the postal logistics network of public postal operator. Proceedings of the 1stLogistics International Conference;2013 Nov 28-30; Belgrade, Serbia; 2013; p. 20-25.

[11] Hakimi SL. Optimum locations of switching centers and the absolute centers and medians of a graph. Operations Research. 1964;12(3):450-459.

[12] Kariv O, Hakimi SL. An algorithmic approach to network location problems. Part II: The p-medians. SIAM Journal of Applied Mathematics. 1979;37(3):539-560.

[13] Daskin MS. Network and Discrete Location: models, algorithms, and applications. New York: John Wiley \& Sons Inc.; 1995.

[14] Toregas C, Swain R, ReVelle C, Bergman L. The location of emergency service facilities. Operations Research. 1971;19(1):1363-1373.

[15] Garey MR, Johnson DS. Computers and Intractability: A Guide to the Theory of NP - Completeness. NewYork: W. H. Freemanand Co.; 1979.

[16] Larson R, Odoni A. Urban Operations Research. New Jersey: Prentice-Hall; 1981.

[17] Statistical Office of the Republic of Serbia. Census of Population, Households and Dwellings in the Republic of Serbia; 2011.

[18] Lisec A, Rosi B, Kavran Z. Holistic thinking approach: case study of post network in Slovenia. Promet - Traffic\&Transportation. 2008;20(2);79-86. 